\title{
The Municipal Solid Waste Management System with Anaerobic Digestion
}

\author{
Przemysław Seruga $\mathbb{1}$
}

check for updates

Citation: Seruga, P. The Municipal Solid Waste Management System with Anaerobic Digestion. Energies 2021, 14, 2067. https://doi.org/ $10.3390 /$ en14082067

Academic Editor: Salvatore Digiesi

Received: 20 March 2021

Accepted: 7 April 2021

Published: 8 April 2021

Publisher's Note: MDPI stays neutral with regard to jurisdictional claims in published maps and institutional affiliations.

Copyright: (C) 2021 by the author. Licensee MDPI, Basel, Switzerland. This article is an open access article distributed under the terms and conditions of the Creative Commons Attribution (CC BY) license (https:// creativecommons.org/licenses/by/ $4.0 /)$.
Department of Bioprocess Engineering, Wroclaw University of Economics and Business, Komandorska 118/120, 53-345 Wroclaw, Poland; przemyslaw.seruga@ue.wroc.pl; Tel.: +48-713-680-872

\begin{abstract}
This study investigated the applied methods for the collection and treatment of an organic fraction of municipal solid waste with anaerobic digestion (AD), including the effects of selective waste collection system introduction. As the research area, data from a waste treatment plant, which collects waste from about 260,000 inhabitants, was used as the selected waste management plan. Biowaste stream management was emphasized. Thus, research on energy recovery and the characteristics of digestate (nutrient and heavy metals content) obtained from biowaste AD was performed. The results of the studies and their quantitative data were interpreted. A significant discrepancy between the assumptions and the actual situation was revealed (up to $20 \%$ year-onyear regarding biowaste). An underestimation of the amount of waste when planning was noted. AD ensures energy recovery from biowaste, which can cover facility electricity needs and material recovery. The digestate might find agricultural usage and become an ecological product. The content of nitrogen $\left(1.5 \%_{\text {dry matter }}\right)$, phosphorus $\left(0.55 \%_{\text {dry matter }}\right)$, potassium $\left(1.0 \%_{\text {dry matter }}\right)$, and organic carbon $(16.0 \%$ dry matter $)$ indicate a positive impact on crops. Furthermore, it can improve the economic balance, by replacing costs with sales revenues.
\end{abstract}

Keywords: biogas; energy recovery; fermentation; organic waste; soil amendment; waste to energy

\section{Introduction}

Waste generation accompanies all human activities. Along with economic development, an increase in the environmental awareness of people has been observed [1]. As a result, an intensification of activities aimed at limiting the generation of waste, or eliminating it, is currently noticeable [2]. Hence, zero waste or circular economy ideas, focusing on eliminating waste generation and enclosed life cycle products, are becoming more widespread [3]. Furthermore, international regulations, e.g., Directive 2006/12/CE [4], Directive 2014/94/UE [5], as well as national, i.e., the Polish Act of Waste [6], concerning municipal solid waste (MSW) volume increment, together with an increase in people's awareness of the need for environmental care and recycling are more evident. Considering that the yearly generation of MSW is estimated at around 2 billion tons [2], MSW management can be seen as one of the most critical issues [7].

Regulations related to environmental protection, including municipal waste management, are subject to specific directives, laws, and ordinances. Many entities' are involved in creating an MSW management system's sustainable design [8]. Generally, a municipal solid waste management system (MSWMS) starts with the waste collection infrastructure, separation centers, waste processing technics, and, if advanced, biogas conversion facilities. However, only a few MSWMS involve a biogas plant, e.g., in Poland, only six. The high costs and/or complexity of the logistical operations have hampered full-scale implementation $[9,10]$. However, waste to energy via biogas seems to be an idea that could become a viable option for countries and cities nowadays. Already, at the beginning of this century, the benefits of AD were defined and divided into three groups: i.e., environmental benefits: odors, carbon dioxide, and methane emission reduction; sanitized nutrient-rich 
fertilizer production; energy benefits: net energy generation, high-quality renewable fuel production, with numerous end-use applications; and economic benefits: cost-effectiveness from a lifecycle perspective [11].

The complexity of a MSWMS with energy recovery via biogas is higher than one without it, mainly because of the perishable products. This feature might increase transportation and storage costs. Furthermore, the MSWMS needs to be adaptable and robust to alter with waste generation's seasonal changes.

When considering MSWMSs, a few assumptions must be made, such as the generated waste in cities, collected by the city collection stations; all costs related to waste collection, transportation, and other operational costs are linear functions [12]. Finally, waste generation must be forecasted with high probability rates. It is also crucial to consider the high investment cost of waste treatment facilities.

Recently in Poland, MSW management has undergone intensive legislative restrictions. The government faces Poles' ecological behavior and underestimating collected waste amount, as evidenced by comparing the European Union and Poland's municipal waste generation [13]. Following the Polish Waste Act [6], national and provincial waste management plans must be created and updated. The current Polish National Waste Management Plan 2022 [14] defines tasks in the field of waste management, analyzes the current state of waste management, forecasts changes in this area, and determines the goals and direction of activities in the field of the waste management [14].

The regional delegation and more detailed guidelines for implementing the specific strategic objectives are encompassed by the Voivodeship Waste Management Plans. One of these binding documents is the Voivodeship Waste Management Plan for the Lower Silesian Region for 2016-2022 [15]. It covers the full range of tasks necessary to create integrated waste management in the Lower Silesian Voivodeship. It also includes analyzing the current state of waste management and the forecasted changes in this area [15].

Nowadays, separate collection of waste is considered as the best management method to fulfill recycling requirements $[16,17]$. Besides packaging waste recovery, it allows for collecting biowaste, which may be up to $50 \%$ of the municipal waste. Anaerobic digestion (AD) can be thought of as the most promising and sustainable process for the treatment of organic waste [18] and an environmentally friendly method for waste management [19]. In source-segregated biowaste $\mathrm{AD}$, in addition to biogas, added value material is also recovered, which can be used on crops [20]. On the other hand, if the biowaste is not segregated by source, the organic fraction is recovered by mechanical-biological treatment (MBT) process, so the agricultural usage of the digestate is limited. Thus, the AD of separately collected biowaste can be a solution to meet recycling rate requirements, combining material and energy recovery. However, the cost to benefit ratio of biogas recovery from MSW depends on many factors, such as energy prices, existing tax concessions, land prices, labor costs, construction and material costs, biofertilizer demand and prices, and the quality of produced biogas, as well as biofertilizer [21].

This study aims to present the currently applied methods of collecting and treating an organic fraction of MSW via AD. The research on energy recovery and the characteristics of digestate obtained from biowaste $\mathrm{AD}$ was performed for competitive advantage and plant financial balance. Furthermore, the waste generation forecast was verified, considering the collected municipal waste amount's current status after the introduction of a separate collection system. The assumptions of the waste management plans were also made with the example of the selected plan and the achieved levels of recycling and preparation for reuse relative to legal requirements.

\section{Materials and Methods}

\subsection{The Research Area Characterization}

Zaklad Gospodarowania Odpadami Gac Ltd. (ZGO Gac) was selected to perform research. The plant is located near Oława, in the Lower Silesia Region, in the southwestern part of Poland, and collects waste from 16 communes and about 260,000 inhabitants. 
The company was established in 1997 and enlarged in 2015, considering the necessity for treatment of non-segregated municipal solid waste. Later on in the analyzed area, a separate collection system was implemented, following the Regulation of the Minister of the Environment of 7 October 2019, using the method of source collection of selected waste fractions, and realized by collecting the following fractions: metals and plastics, paper, glass, biowaste, and residual/mixed waste [22]. Thus, another enlargement became necessary.

Currently, ZGO Gac has a modern mechanical sorting installation: a hopper with bag breaker, drum sieve, seven opto-pneumatic separators, four metal separators, and five sorting cabinets with a total processing capacity of about 100,000 tons of waste per year. A complement to the mechanical processing is the refused-derived fuel (RDF) production line with a yearly capacity of 15,000 tons, consisting of two shredders, a windshifter, metal separator, and belt dryer.

The facility for biological treatment consists of two Kompogas ${ }^{\circledR}$ AD chambers, operating in thermophilic conditions $\left(54{ }^{\circ} \mathrm{C}\right)$, and a composting installation. The $\mathrm{AD}$ also includes combined heat and power (CHP) units. The plant has two CHP units (Caterpillar CG132-12) with a capacity of $600 \mathrm{kWe}$, each. The first AD chamber operates on the mechanically sorted organic fraction of municipal solid waste generated in the sorting area. As the first of this type in Poland, the second chamber has been dedicated to processing source-segregated biowaste. The composting facility consists of six enclosed reactors, with aeration and irrigation, and a maturation field.

Based on the amount of waste received by ZGO Gac between 2016 and 2019, streams were defined as: packaging fractions, biowaste, and residual/mixed waste. They were compared with the forecasts included in the Plan for the Lower Silesian Voivodeship [15]. Second, exploitation data were analyzed to determine energy recovery possibility via AD of biowaste. Third, the obtained digestate was characterized to determine agricultural usage possibility. Finally, a financial analysis in the field of energy and digestate was carried out.

\subsection{The Analytical Methods}

The digestate derived from source-segregated biowaste was obtained from the second digester chamber. During one year, eight samples were collected (two samples four times per year, to verify potential seasonal changes) and characterized. The average values are reported.

A biogas analyzer (DP-28, Nanosens, Tarnowo Podgórne, Poland) was used to determine methane content, carbon dioxide, hydrogen sulfide, oxygen, and ammonia. Average values are reported.

The suspended solids (SS), dry organic mass, and $\mathrm{pH}$ were determined as per the standard methods [23].

The heavy metals: chrome $(\mathrm{Cr})$, phosphorus $(\mathrm{P})$, cadmium $(\mathrm{Cd})$, nickel $(\mathrm{Ni})$, lead $(\mathrm{Pb})$, potassium $(\mathrm{K})$, and mercury $(\mathrm{Hg})$ were determined following the standards: PN-EN 16319+ A1:2016-02 and PN-EN 15960:2011, using atomic emission spectrometry with inductively coupled plasma (ICP-AES) after digestion in nitric acid $\left(\mathrm{HNO}_{3}\right)$ and hydrochloric acid $(\mathrm{HCl})$ in the ratio of 3:1 by vol, using a Shimadzu ICPE-9820 (Shimadzu, Kyoto, Japan).

The total organic carbon (TOC) was determined following the standard: PN-EN 13137: 2004, using Vario TOC Cube (Elementar Analysensysteme GmbH, Langenselbold Germany).

\section{Results and Discussion}

The ZGO Gac was designed considering the treatment necessity for non-segregated municipal solid waste. This new approach to the MSW problem and source-segregation has been expanded in recent years [24,25]. Over 35 million euros were invested. However, some shortcomings can be noticed, mainly regarding the treatment capacity of sourcesegregated waste. The investment process is long (about five years) and costly; thus, it requires waste generation forecasts with high probability rates and a relatively constant legal system. 
The predicted amounts of waste in the Voivodeship Waste Management Plan for the Lower Silesian Region for 2016-2022 [15], and those received by ZGO Gac are shown in Table 1.

Table 1. The predicted and collected waste amounts from the ZGO Gac area.

\begin{tabular}{|c|c|c|c|c|c|c|c|c|c|c|}
\hline \multirow{3}{*}{ Waste Fraction } & \multicolumn{2}{|c|}{2016} & \multicolumn{2}{|c|}{2017} & \multicolumn{2}{|c|}{2018} & \multicolumn{2}{|c|}{2019} & \multicolumn{2}{|c|}{2020} \\
\hline & \multicolumn{2}{|c|}{$\begin{array}{l}\text { Waste Amount } \\
\text { (Ton/Year) }\end{array}$} & \multicolumn{2}{|c|}{$\begin{array}{l}\text { Waste Amount } \\
\text { (Ton/Year) }\end{array}$} & \multicolumn{2}{|c|}{$\begin{array}{l}\text { Waste Amount } \\
\text { (Ton/Year) }\end{array}$} & \multicolumn{2}{|c|}{$\begin{array}{l}\text { Waste Amount } \\
\text { (Ton/Year) }\end{array}$} & \multicolumn{2}{|c|}{$\begin{array}{l}\text { Waste Amount } \\
\text { (Ton/Year) }\end{array}$} \\
\hline & $\underset{[15]}{\text { Assumed }}$ & Collected & Assumed & Collected & Assumed & Collected & $\begin{array}{c}\text { Assumed } \\
{[15]}\end{array}$ & Collected & $\begin{array}{c}\text { Assumed } \\
{[15]}\end{array}$ & Collected \\
\hline $\begin{array}{l}\text { Residual/Mixed solid } \\
\text { waste }\end{array}$ & 56,170 & 60,059 & 53,594 & 65,659 & 50,956 & 63,887 & 4714 & 65,050 & 43,532 & 62,238 \\
\hline Biowaste & 5754 & 8195 & 6303 & 9777 & 6873 & 11,720 & 7251 & 13,770 & 7614 & 19,268 \\
\hline $\begin{array}{l}\text { Packaging fractions } \\
\text { (paper, glass, plastics, } \\
\text { and metals) }\end{array}$ & 6977 & 8549 & 7816 & 9349 & 8614 & 12,075 & 9282 & 12,662 & 9771 & 14,822 \\
\hline
\end{tabular}

A systematic decrease in the amount of collected residual/mixed municipal was assumed, with annual dynamics from -4.5 to $7.7 \%$ year-on-year (Table 1). This waste stream's decline should have been accompanied by a decrease in the amount of residues to be landfilled, as an obvious consequence. In turn, the mass of separate all municipal waste fractions collected ought to have increased: biowaste and packaging fractions (glass, paper, plastics, and metals). A yield increment from 5.0\% to $9.5 \%$ for biowaste, and from $5.2 \%$ to $12.0 \%$ for the packaging factions, was assumed in the plan. Furthermore, year-on-year changes should have been smaller (Table 1).

The data obtained by ZGO Gac indicated stabilization of the volume of collected residual/mixed municipal waste, accompanied by a lack of a downward trend (Table 1). As for packaging fractions, an enormous yield (by about 29\%) was observed in 2018 comparing to 2017. Followed by stabilization in 2019, the volume of collected waste stabilized, and again there was a slight increase in 2020 (Table 1). A significant (around $20 \%$ year-on-year) increment in the amount of biowaste was noticed.

Considering the assumed and collected amounts of municipal waste, significant discrepancies were noticed, which affected the company's capacity and investment plans. Regarding the residual/mixed municipal waste, instead of the assumed decrease in mass, an increase was noticed concerning 2016.

It can be noticed that the introduced separate waste collection system, "door-to-door" in the case of rural and single-family housing and assuming disposal in various standard bins regarding multi-family housing, is bringing the expected results. However, some disproportions in the quality of collected waste were noticed. Waste from the shared containers was characterized by almost twice as high contamination, i.e., the biowaste from multi-family housing contained over $30 \%$ plastics and glass.

It should also be noted that in 2018 and 2019, ZGO Gac organized informative campaigns about separate waste collection, addressed mainly to children and adolescents. During the educational workshops, almost 18,000 citizens have visited ZGO Gac. Based on this, it can be assumed that the proper separate waste collection system and informative campaign affected the collected waste amounts in the analyzed region.

Incorrect assumptions in waste management plans, which are often observed in Poland, impacted this plant, i.e., in the plans, processing capacity limits were established, which proved to be insufficient for the actual requirements resulting from the amount of waste generated by inhabitants. This problem was mainly for biowaste, which must be processed in composting or biogas facilities.

The amount of residual/mixed municipal waste should be considered as well. It was assumed in the waste plans that a drop-in collected amounts should also limit the number of residues to be landfilled (Table 1). However, with a stable residual/mixed waste stream level, the amount of residues remains similar. Thus, possible landfill lifetime is limited and changes waste management plans' assumptions, including for the examined 
Voivodeship Plan [15]. Despite technological progress, landfilling remains the only possible management path for residues after waste treatment, especially mixed municipal waste [26]. Even after combustion, the generated residues have to be landfilled. Although landfilling is at the lowest level of the waste treatment hierarchy, it cannot be eliminated, considering economic efficiency [26]. However, it should be noted that the quantities to be landfilled could be limited, for example, by improving the efficiency of a separate collection system of municipal waste or using thermal treatment [27].

Based on this, it can be seen that investments must still be made to reach the European Union targets and keep up with the current trends that deviate from the forecasts. That might be changed by citizens' behavior, legal regulations affecting the waste collection system, and educational activity. The daily behavior of the individual citizen is challenging to foresee. An aggregation can be predicted. However, paradoxically, the amount of waste and its type and quality depends mainly on the individual. Due to this, it is not easy to prepare accurate forecasts.

Regardless of the assumptions propriety, the biowaste fraction has become the main stream of segregated source waste; thus, its efficient treatment will be crucial for the waste management system. The yearly biowaste generation increased from 33 kilos per person in 2016, to 47.3 kilos per person in 2018, to 55.6 kilos per person in 2019 in the analyzed area; thus, biowaste has become an even more crucial stream in municipal waste management.

Despite the environmentally friendly aspect of $\mathrm{AD}$, its cost to benefit ratio should also be considered. The total operational costs of energy recovery from MSW with AD should include the entire MSWMS. The collection system starts through transportation and waste storage stations, and ending with biogas production and final disposal. The costs might be higher than the financial gain. However, considering the social and environmental aspects, i.e., reducing pollution and waste recycling, the benefits are surplus.

The AD of separately collected biowaste was evaluated at the full-scale plant (ZGO $\mathrm{Gac}$ ) in a previous study and was found to be a stable process [20]. For instance, the $\mathrm{pH}$ value reached 8.3-8.4 in the inlet section, with a slight growth to 8.6 in the outlet, while it was found that the $\mathrm{pH}$ value should be between 7.2 and 7.8 [28]; however, this might be unique to the particular facility and be influenced by temperature and sampling [20]. The concentration of acetic acid was between 1.0 and $1.2 \mathrm{~g} / \mathrm{kg}$, while propionic acid content ranged from 15 to $32 \mathrm{mg} / \mathrm{kg}$ [20]. The obtained volatile fatty acid concentrations, at levels around $1.2 \mathrm{~g} / \mathrm{kg}$, indicate a no-risk exploitation. [29]. The obtained biogas yield was at the level of $111.1 \mathrm{~m}^{3} /$ ton [20]. The obtained biogas productivity was similar to the results reported by other researchers [30]. The composition of biogas is presented in Table 2. The methane content in biogas was at a level of about $60 \%$, which directly affected the production of electricity in CHP units. Another biogas quality parameter is the hydrogen sulfide content. This was maintained at a level of about $240 \mathrm{ppm}$ (Table 2) by the addition of a desulfurizing agent (ferric chloride solution (PIX 116, Kemipol, Police, Poland) to prevent $\mathrm{CHP}$ unit damages. The $\mathrm{O}_{2}$ content did not exceed $0.2 \%$ (Table 2), which confirms there were no leaks in the facility.

Table 2. The composition of biogas.

\begin{tabular}{cc}
\hline Parameter & Content in Biogas \\
\hline Methane $\left(\mathrm{CH}_{4}\right)(\%$ vol $)$ & $59.0 \pm 5.0$ \\
Carbon dioxide $\left(\mathrm{CO}_{2}\right)(\%$ vol $)$ & $39.0 \pm 3.4$ \\
Oxygen $\left(\mathrm{O}_{2}\right)(\%$ vol $)$ & $<0.2$ \\
Ammonia $\left(\mathrm{NH}_{3}\right)(\mathrm{ppm})$ & $180.0 \pm 20.0$ \\
Hydrogen sulfide $\left(\mathrm{H}_{2} \mathrm{~S}\right)(\mathrm{ppm})$ & $238.0 \pm 30.0$ \\
\hline
\end{tabular}

As mentioned in the literature review, the biogas plant heat and electrical requirement is about $22 \%$ of the energy produced for dry AD [11]; however many factors influence energy production, e.g., feedstock, local conditions, and plant operation [31]. In 2018 the company spent over 49,000 euros on the purchase of electricity. The revenue from the 
sale of electricity amounted to about 105,500 euros, without profit from the sale of green certificates. In 2018 the total electricity production reached almost $6000 \mathrm{MWh}$, of which over $2100 \mathrm{MWh}$ was sold. Furthermore, $235 \mathrm{MWh}$ had to be purchased. Thus, it can be assumed that energy recovery allowed for covering the plant electricity demands with a surplus. Moreover, Banks et al. [30] summarized the AD's energy balance as exceeding needs for feedstock processing. The authors determined gross electrical output from CHP units at about $890,074 \mathrm{kWh}$, followed by the total plant-parasitic electricity at $277,422 \mathrm{kWh}$; during the $\mathrm{AD}$, over 426 days of food waste was collected, mainly from domestic kitchens [30]. It should also be mentioned that the unit cost of purchasing electricity was over twice as high as the unit electricity sales revenue. Based on this, it can be stated that the usage of the produced energy for the plants own needs first is more cost-effective. Energy purchases should be kept to a minimum, e.g., by balancing energy demand with its production or biogas storage.

The financial data of ZGO Gac from the first eight months of 2020 was analyzed to determine the total balance of MSW treatment via AD. During this period, the company's income reached over 360,000 euros (including gate fees and electricity sales), while expenditures reached over 1 million euros. However, when considering and calculate savings obtained from, e.g., waste weight loss, waste type change, lack of heat, and electricity purchase, the total balance becomes a surplus, at the level of 180,000 euros. The ZGO Gac example can confirm that even if the total costs of AD are higher than the financial profit, the total balance might be surplus when the environmental benefits are considered.

Considering energy recovery, AD brings more significant benefits than single composting [8], and can be a competitive advantage. Biowaste AD should also enable organic recycling; thus, the obtained digestate was characterized. A comparison of the produced digestate and the requirements for organic amendments [32] is presented in Table 3.

Table 3. A characterization of the digestate derived from biowaste.

\begin{tabular}{ccc}
\hline Parameter & Digestate & Required Levels [32] \\
\hline Chrome $(\mathrm{Cr})\left(\mathrm{mg} / \mathrm{kg}_{\text {dry matter }}\right)$ & $32.0 \pm 8.0$ & Max. 100 \\
Phosphorus $\left(\mathrm{P}_{2} \mathrm{O}_{5}\right)\left(\%_{\text {dry matter }}\right)$ & $0.55 \pm 0.14$ & Min. 0.2 \\
Cadmium $(\mathrm{Cd})\left(\mathrm{mg} / \mathrm{kg}_{\text {dry matter }}\right)$ & $0.36 \pm 0.09$ & Max. 5 \\
Nickel $(\mathrm{Ni})\left(\mathrm{mg} / \mathrm{kg}_{\text {dry matter }}\right)$ & $20.0 \pm 5.0$ & Max. 60 \\
Lead $(\mathrm{Pb})\left(\mathrm{mg} / \mathrm{kg}_{\text {dry matter }}\right)$ & $29.0 \pm 7.0$ & Max. 140 \\
Potassium $\left(\mathrm{K}_{2} \mathrm{O}\right)(\%$ dry matter & Min. 0.5 \\
Mercury $(\mathrm{Hg})\left(\mathrm{mg} / \mathrm{kg}_{\text {dry matter }}\right)$ & $1.0 \pm 0.1$ & Max. 2 \\
Total nitrogen $(\%$ dry matter $)$ & $<0.1$ & Min. 0.3 \\
Total organic carbon $(\mathrm{TOC})(\%$ dry matter & $1.5 \pm 0.3$ & - \\
pH value $(-)$ & $16.0 \pm 3.0$ & - \\
Water content $(\%)$ & $8.5 \pm 0.3$ & - \\
Organic matter $(\%$ dry matter & $56.4 \pm 3.9$ & Min. 30 \\
\hline
\end{tabular}

The soil amendments quality was determined by several indicators [32]. The amendments must first fulfill requirements for ensuring safe usage and, second, enrich the soil by, e.g., containing proper organic matter (OM). The OM of the digestate was at the level of $34.2 \%$, which was higher than the required minimum (30\%) [32]. The balance between carbon, nitrogen, and phosphorus is essential to digestate agronomic usage [33]. The phosphorus content was over two times higher than the required level, followed by five times higher nitrogen concentration (Table 3), which may positively affect the soil.

Furthermore, the heavy metal content must also be maintained to ensure safe food and animal feed production [34]. As this affects environmental contamination, value limits are set. The examined digestate fulfilled the requirements (Table 3), insomuch as values of the heavy metals, i.e., chrome $(32.0 \mathrm{mg} / \mathrm{kg})$, nickel $(20.0 \mathrm{mg} / \mathrm{kg})$, and lead $(29.0 \mathrm{mg} / \mathrm{kg})$, did not exceed the limit values (Table 3 ). 
Digestion residues are characterized by different dry matter levels (DM), which can be related to the feedstock and post-treatment process. In case of digestion of feedstocks with high water content, the digestate should have a lower dry matter content. The kind of post-treatment process, e.g., screw-pressing or drying, may affect the digestate moisture. The content of DM impacts the viscosity. The DM of around $20 \%$ was too high to be easily applied directly [33]. Thus, due to the investigated digestate's moisture (56.4\%) (Table 3), dewatering and composting should be considered.

The positive usage of digestate as a soil amendment was confirmed by some researchers, while other researchers reported the danger posed by digestates [35] and sewage sludges [36]; thus, agricultural usage requires careful control, including hygienic safety. The digestate may cause potential environmental problems due to nutrient volatilization (i.e., nitrogen); thus, its valorization should be considered [37]. Moreover, digestate use problems are mainly due to odors that can arise during digestate storage, transport, and land spreading. In this case, digestate composting might be a solution.

If the digestate does not meet the requirements, it must be landfilled or composted and used for landfill rehabilitation. Due to limited management possibilities, MBT plants must bear the waste disposal costs (around 20 EUR per ton in the examined plant). If the digestate is used for soil amendment, it may be sold for about 5 EUR per ton. Thus, except for organic recycling, financial benefits might be obtained for waste treatment plants when processing source segregated waste.

\section{Conclusions}

MSW management should be considered as a strategic concern for municipalities. Various factors, i.e., collection system, transport organization, and treatment plans, impact MSWMS.

A separate collection implementation is necessary to improve the waste management system and fulfill recycling requirements. However, the MSWMS has to be prepared for this execution. Due to the high investment costs of waste treatment facilities, waste generation must be forecasted with high probability rates. Meanwhile, a significant discrepancy between assumptions and the actual situation was revealed in the analyzed area, mainly in residual/mixed solid waste and biowaste. This can affect waste treatment plants, citizens, and even whole MSWMSs in the area. Thus, continual investments are necessary to achieve the requirements and to follow the current trends that differ from the forecasts. Furthermore, the interval of the forecast updates should be verified to reduce the discrepancies.

A MSWMS, including waste to energy with AD, could be a feasible option, even if its complexity is higher. AD can be considered as the best biowaste treatment method, confirming statements presented in the literature. Besides the biogas and generated renewable energy, the digestate can be reused to cultivate crops.

Considering the energy benefits of $\mathrm{AD}$, it also ensures energy recovery with a surplus. The analyzed biogas plant in 2018 generated almost $6000 \mathrm{MWh}$, of which over $2100 \mathrm{MWh}$ was sold. If we consider the total balance of the biogas plant, it was surfeit at 180,000 euros in eight months of 2020.

Regarding the environmental benefits, AD brings odor and greenhouse gas emissions reduction. The AD may also ensure material recovery. The digestate derived from biowaste fulfills the required levels for agricultural usage. The high concentration of nitrogen $(1.5 \% \mathrm{DM})$, phosphorus $(0.55 \% \mathrm{DM})$, potassium $(1.0 \% \mathrm{DM})$, and organic carbon $(16.0 \% \mathrm{DM})$ indicate a positive impact on soil. It should also be stressed that the material recovery impacts the waste treatment plants' financial balance. The revenues from biofertilizer sales might replace the disposal costs; thus, the biowaste AD can become a competitive advantage for waste treatment plants because of energy recovery and organic recycling. This advantage affects the financial balance of waste treatment plants; which seems to be insufficiently emphasized in the literature. A further study could assess the long-term effects of AD, considering the lifecycle perspective. 
The main concerns that can limit the direct disposal of digestate on crops remain dry matter (DM) content (about $43.5 \%$ ) and the arising odors during the soil's spreading. Thus, digestate dewatering and further composting should be investigated. A comparison of compost derived from biowaste and the organic fraction obtained from mechanical treatment of residual/mixed municipal solid waste (biodegradable fraction) would also be valuable.

Funding: This research received no external funding.

Institutional Review Board Statement: Not applicable.

Informed Consent Statement: Not applicable.

Data Availability Statement: Not applicable.

Acknowledgments: This research was supported by Zaklad Gospodarki Odpadami Gac Ltd. in Poland.

Conflicts of Interest: The author declares no conflict of interest.

\section{References}

1. Zhang, L.P.; Zhu, Z.P. Can smart waste bins solve the dilemma of household solid waste sorting in China? A case study of Fuzhou City. Pol. J. Environ. Stud. 2020, 29, 3943. [CrossRef]

2. Abad, V.; Avila, R.; Vicent, T.; Font, X. Promoting circular economy in the surroundings of an organic fraction of municipal solid waste anaerobic digestion treatment plant: Biogas production impact and economic factors. Bioresour. Technol. 2020, $283,10-17$. [CrossRef]

3. Geissdoerfer, M.; Savaget, P.; Bocken, N.; Hutlink, E.J. The Circular Economy-A new sustainability paradigm? J. Clean. Prod. 2017, 143, 757-768. [CrossRef]

4. EU. Directive 2006/12/CE of the European Parliament and of the Council of 5 April 2006 on Waste. Available online: https: / / eur-lex.europa.eu/eli/dir/2006/12/oj (accessed on 18 September 2020).

5. EU. Directive 2014/94/UE of the European Parliament and of the Council of 22 October 2014 on the Deployment of Alternative Fuels Infrastructure. Available online: https:/ / eur-lex.europa.eu/eli/dir/2014/94/oj (accessed on 18 September 2020).

6. Polish Regulation. The Act of December 142012 on Waste, (Journal of Laws 2020 Item 797). (In Polish). Available online: https: / isap.sejm.gov.pl/isap.nsf/DocDetails.xsp?id=WDU20130000021 (accessed on 25 September 2020).

7. Aghbashlo, M.; Tabatabaei, M.; Soltanin, S.; Ghanavat, H. Biopower and biofertilizer production from organic municipal solid waste: An exergoenvironmental analysis. Renew. Energy 2019, 143, 64-76. [CrossRef]

8. Heidari, R.; Yazdanparast, R.; Jabbarzadeh, A. Sustainable design of a municipal solid waste management system considering waste separators: A real-world application. Sustain. Cities Soc. 2019, 47, 101457. [CrossRef]

9. Bachmann, N. Design and engineering of biogas plants. In The Biogas Handbook; Woodhead Publishing Series in Energy: Cambridge, UK, 2013; pp. 191-211.

10. Abbasi, T.; Tauseef, S.M.; Abbasi, S.A. Biogas Capture from Solid Waste. In Biogas Energy; Springer: New York, NY, USA, 2012; Volume 2, pp. 105-143.

11. International Environmental Agency (IEA). Biogas and More: Systems and Markets Overview of Anaerobic Digestion; AEA Technology Environment: Paris, France, 2001.

12. Zhang, Y.; Huang, G.H.; He, L. A multi-echelon supply chain model for municipal solid waste management system. Waste Manag. 2014, 34, 553-561. [CrossRef]

13. Antczak, E. Regional patterns in dumping sites in Poland-Analysis in context of the new "Sustainable" waste policy. Pol. J. Environ. Stud. 2020, 29, 1037-1049. [CrossRef]

14. Polish Regulation: National Waste Management Plan 2022. Resolution No 88 of the Council of Ministers of July 1 2016, (Journal of Laws 2016, Item 784) (In Polish). Available online: https:/ / bip.mos.gov.pl/strategie-plany-programy/krajowy-plan-gospodarkiodpadami/krajowy-plan-gospodarki-odpadami-2022-przyjety-w-2016-r/krajowy-plan-gospodarki-odpadami-2022-przyjetyprzez-rade-ministrow-uchwala-nr-88-z-dnia-1-lipca-2016-r/ (accessed on 25 September 2020).

15. Polish Regulation: Voivodeship Waste Management Plan for the Lower Silesian Region for the years 2016-2022. Resolution of the Lower Silesian Regional Assembly of 21st December 2017. (No. XLIII/1450/17). (In Polish). Available online: http: / / bip.umwd.dolnyslask.pl/dokument,iddok,29125,idmp,22,r,r (accessed on 12 June 2019).

16. Vaccari, M.; Di Bella, V.; Vitalli, F.; Collivignarelli, C. From mixed to separate collection of solid waste: Benefits for the town of Zavidovići (Bosnia and Herzegovina). Waste Manag. 2013, 33, 277. [CrossRef]

17. Ciuta, S.; Apostol, T.; Rusu, V. Urban and rural MSW stream characterization for separate collection improvement. Sustainability 2015, 7, 916. [CrossRef]

18. Khoshnevisan, B.; Tsapekos, P.; Alvardo-Morales, M.; Angelidaki, I. Process performance and modelling of anaerobic digestion using source-sorted organic household waste. Bioresour. Technol. 2018, 247, 486-495. [CrossRef] 
19. Seruga, P.; Krzywonos, M.; Wilk, M. Treatment of By-Products Generated from Anaerobic Digestion of Municipal Solid Waste. Waste Biomass Valor 2019, 11, 4933-4940. [CrossRef]

20. Seruga, P.; Krzywonos, M.; Seruga, A.; Niedźwecki, Ł.; Pawlak-Kruczek, H.; Urbanowska, A. Anaerobic Digestion Performance: Separate Collected vs. Mechanical Segregated Organic Fractions of Municipal Solid Waste as Feedstock. Energies 2020, $13,3768$. [CrossRef]

21. Ramasamy, E.V.; Gajalaksl, S.; Sanjeevi, R.; Jithesh, M.N.; Abbasi, S. Feasibility studies on the treatment of dairy wastewaters with up flow anaerobic sludge blanket reactors. Bioresour. Technol. 2004, 93, 209-212.

22. Polish Regulation: Regulation of the Minister of the Environment of October 72019 on the Detailed Method of Selective Collection of Selected Waste Fractions and Realized by Collecting the Following Fractions: Metals and Plastics; Paper; Glass, Biowaste and Residual. (Journal of Laws 2019, Item 2028). (In Polish). Available online: http:/ /isap.sejm.gov.pl/isap.nsf/DocDetails.xsp?id= WDU20190002028 (accessed on 26 September 2020).

23. Rice, E.W.; Baird, R.B.; Eaton, A.D.; Clesceri, L.E. Standard Methods for Examination of Water and Wastewater, 22nd ed.; American Water Works Association: Alexandria, VA, USA, 2012.

24. Rolewicz-Kalińska, A.; Lelicińska-Serafin, K.; Manczarski, P. The circular economy and organic fraction of municipal solid waste recycling strategies. Energies 2020, 13, 4366. [CrossRef]

25. Abis, M.; Bruno, M.; Kuchta, K.; Simon, F.-G.; Grönholm, R.; Hoppe, M.; Fiore, S. Assessment of the Synergy between Recycling and Thermal Treatments in Municipal Solid Waste Management in Europe. Energies 2020, 13, 6412. [CrossRef]

26. Zaman, A.U. A comprehensive study of the environmental and economic benefits of resource recovery from global waste management systems. J. Clean. Prod. 2016, 124, 41-50. [CrossRef]

27. Salman, C.A.; Schwede, S.; Naqvi, M.; Thorin, E.; Yan, J. Synergistic combination of pyrolysis, anaerobic digestion, and CHP plants. Energy Procedia 2019, 158, 1323-1329. [CrossRef]

28. Drosg, B. Process Monitoring in Biogas Plants; IEA Bioenergy: Tulln, Austria, 2013; ISBN 9781910154038.

29. Paritosh, K.; Kushwaha, S.K.; Yadav, M.; Pareek, N.; Chawade, A.; Vivekanand, V. Food Waste to Energy: An Overview of Sustainable Approaches for Food Waste Management and Nutrient Recycling. BioMed Res. Int. 2017, 2017, 1-19. [CrossRef] [PubMed]

30. Banks, C.J.; Chesshire, M.; Heaven, S.; Arnold, R. Anaerobic digestion of source-segregated domestic food waste: Performance assessment by mass and energy balance. Bioresour. Technol. 2011, 102, 612-620. [CrossRef]

31. RIS International. Generating Biogas from Source Separated Organic Waste for Energy Production. Available online: http: / / www.toronto.ca / eia (accessed on 29 January 2007).

32. Polish Regulation: The Ordinance of the Minister of Agriculture and Rural Development of 18 June 2008 on Implementation of Certain Provisions of the Act on Fertilisers and Fertilizing. (Journal of Laws 2008, Item 765). (In Polish). Available online: http:/ /isap.sejm.gov.pl/isap.nsf/DocDetails.xsp?id=wdu20081190765 (accessed on 25 September 2020).

33. Teglia, C.; Tremier, A.; Martel, J.L. Characterization of solid digestates: Part 2, assessment of the quality and suitability for composting of six digested products. Waste Biomass Valor 2011, 2, 113. [CrossRef]

34. Isam, H.; Gómez-Brandóm, M.; Ascher, J. Manure-based biogas fermentation residues-Friend or foe of soil fertility? Soil Biol. Biochem. 2015, 84, 1-14. [CrossRef]

35. Möller, K.; Müller, T. Effects of anaerobic digestion on digestate nutrient availability and crop growth: A review. Eng. Life Sci. 2012, 12, 242. [CrossRef]

36. Zawadzki, P.; Głodnik, M. Environmental Safety Assessment of Fertilizer Products. Pol. J. Environ. Stud. 2020, 30, 11. [CrossRef]

37. Jimenez, R.; Markou, G.; Tayibi, S.; Barakat, A.; Chapsal, C.; Monlau, F. Production of Microalgal Slow-Release Fertilizer by Valorizing Liquid Agricultural Digestate: Growth Experiments with Tomatoes. Appl. Sci. 2020, 10, 3890. [CrossRef] 